\title{
Phytotoxic Effects of Benzimidazole Fungicides on Bedding Plants
}

\author{
Marc W. van Iersel ${ }^{1}$ and Bruce Bugbee \\ Crop Physiology Laboratory, Department of Plants, Soils, and Biometeorology, Utah State University, \\ Logan, UT 84322-4820
}

Additional index words. Benlate DF, photosynthesis, petunia, Petunia $\times$ hybrida

\begin{abstract}
Benzimidazoles are effective and widely used fungicides, but they may be phytotoxic. We studied the effects of a single drench application of six benzimidazoles and one acetanilide fungicide on photosynthetic gas exchange, growth, development, and nutrient levels of four species of bedding plants in twenty growth-chamber and four greenhouse studies. Daily carbon gain and carbon-use efficiency were calculated from continuous crop gas-exchange measurements in the growth chambers. The maximum labeled rate of Benlate DF caused a 7- to 10-day decrease in net photosynthesis and daily carbon gain in transplants of all species. It also caused pronounced interveinal chlorosis and a 2- to 3-day delay in flowering. Growth of Benlate DF-treated plants was reduced more at high $(90 \%)$ than at low $(60 \%$ to $80 \%)$ relative humidity. Benlate DF had severe effects on 2-week-old petunia (Petunia ×hybrida) seedlings in plug flats, reducing photosynthesis $25 \%$ to 57\%. Cleary's 3336 WP decreased photosynthesis in some trials. Benlate DF reduced photosynthesis within 24 hours, but 3336 WP effects did not become apparent until 1 week after the treatment. This suggests different modes of inhibition. 3336 WP also caused leaf-tip and marginal chlorosis in impatiens (Impatiens wallerana). Mertect 340-F was extremely phytotoxic but is not labeled for drench applications (it was included because of its chemical similarity to other benzimidazoles). The only benzimidazole fungicide that did not reduce photosynthesis was Derosal, but it caused slight interveinal chlorosis in some studies with petunia. Benlate DF and Derosal decreased leaf Ca levels. Subdue (or metalaxyl), an acetanilide fungicide, did not affect photosynthesis or cause any visual symptoms. Our results indicate that some benzimidazole fungicides can cause growth reductions and visual damage in bedding plants.
\end{abstract}

Benzimidazoles and thiophanates are a class of systemic fungicides that control a wide range of fungi at relatively low doses (Delp, 1987). Benomyl, the active ingredient in Benlate WP and Benlate DF (Du Pont) is especially effective because it penetrates plants better than carbendazim (MBC; methyl 2-benzimidazolecarbamate), its fungitoxic breakdown product (Upham and Delp, 1973). However, since the introduction of benomyl (Delp and Klopping, 1968), there have been many reports about side effects on plants. Carbendazim delays senescence in wheat (Triticum aestivum L.) (Tripathi et al., 1982), while benomyl also has cytokinin-like activity in soybean (Glycine Max (L.) Merr.) callus, radish (Raphanus sativus L.) cotyledons, (Skene, 1972), celery germination (Apium graveolens L.), and betacyanin production in Amaranthus (Thomas, 1974).

Benomyl can also be phytotoxic. Benomyl reduced the growth of cucumber (Cucumis sativus L.), loblolly pine (Pinus taeda L.), lettuce (Lactuca sativa L.), American elm (Ulmus americana L.), marigold (Tagetes $\mathrm{sp}$.), and sycamore (Platanus occidentalis L.) (Rouchaud et al., 1985; Schreiber and Hock, 1975; Stumpff and South, 1991; Woo and Wick, 1995). Not all species seem to be equally sensitive to benomyl. Corn (Zea mays L.) and pea (Pisum sativum $\mathrm{L}$.) were not affected, while turfgrass growth was stimulated by benomyl in the soil (Schreiber and Hock, 1975). Benomyl

Received for publication 15 Dec. 1995. Accepted for publication 8 July 1996. This research was supported by the Utah State Univ. Agricultural Experiment Station, Logan, UT 84322-4820. Approved as journal paper no. 4838. We thank Derek Knight, Gus Koerner, Oscar Monje, and Tim Grotenhuis for their technical assistance, Keith Tolson and Anson Moye for their analysis of the Benlate samples, and Jim Faust, John White, and Sherm Thompson for their critical reviews of this manuscript. Mention of brand names is for information only and does not constitute an endorsement to the exclusion of other products that might also be suitable. The cost of publishing this paper was defrayed in part by the payment of page charges. Under postal regulations, this paper therefore must be hereby marked advertisement solely to indicate this fact.

${ }^{1}$ To whom reprint requests should be addressed. Current address: Dept. of Horticulture, Georgia Station, Univ. of Georgia, Griffin, GA 30223-1797. caused veinal discoloration in Swedish ivy (Plectranthus australis) (Baxter et al., 1975), while tomato (Lycopersicon esculentum Mill.) seedlings developed chlorosis and stunting at higher rates (Mihuta-Grimm et al., 1990).

Benomyl breaks down to MBC and BIC ( $n$-butyl isocyanate) (Tang et al., 1993). BIC can subsequently react to produce $n$ butylamine or DBU ( $N, N$-dibutylurea), and DBU concentrations of up to $8.85 \%$ have been found in unopened Benlate boxes (Moye et al., 1994). Dibutylurea reduces growth and inhibits photosynthesis of hydrilla (Hydrilla verticillata L. f. Royle) (Shilling et al., 1994) and may be partly responsible for benomyl effects on plant growth.

In the late 1980s, many commercial greenhouse and foliage growers reported crop injury after the use of Benlate DF. These claims have renewed research interest into the possible phytotoxic effects of benomyl. Although there is ample evidence that Benlate can reduce plant growth, it is not clear what physiological processes are affected. To understand the effects of benomyl on plants, we conducted a series of studies to quantify the effects of Benlate DF and related fungicides on gas exchange, growth, development, and nutrient levels of different crops.

\section{Materials and Methods}

Plant material. Impatiens (Impatiens wallerana, 'Accent Lilac'), cucumber ('Dasher 11'), celosia (Celosia plumosa, Kimono mix), and petunia (Petunia $\times$ hybrida, several cultivars) were used to study the possible phytotoxicity of fungicides. Seeds were planted in soilless media [peat: perlite, 1:1 (v/v) with added limestone] or seedlings in plug flats were obtained from commercial growers. Seedlings were transplanted into black plastic flats with soilless media and grown in the greenhouse or growth chamber. None of the plants was exposed to any pesticides before the fungicide treatments.

Fungicides. An overview of the fungicides used in this research is given in Table 1. All Benlate lots were analyzed for DBU content at the Pesticide Research Laboratory of the Univ. of Florida, 
Table 1. The active ingredient, chemical name, and dibutylurea (DBU) content of the fungicides used in these studies.

\begin{tabular}{llr}
\hline \hline Trade name & Active ingredient ${ }^{2}$ & \% DBU \\
\hline Benlate DF, lot 311 & Benomyl (50\%) & 0.36 \\
Benlate DF, lot 193 & Benomyl (50\%) & 0.41 \\
Benlate DF, lot 688 & Benomyl (50\%) & 0.28 \\
Benlate DF, lot AG29098048 & Benomyl (50\%) & $---{ }^{\mathrm{y}}$ \\
Benlate WP & Benomyl (50\%) & 0.42 \\
Derosal & Carbendazim (59.4\%) \\
Mertect 340-F & Thiabendazole (42\%) & --- \\
Cleary's 3336 WP & Thiophanate methyl (50\%) & --- \\
Banrot & Thiophanate methyl (25\%) and etridiazol (15\%) & --- \\
Subdue & Metalaxyl (25.1\%) & --- \\
\hline
\end{tabular}

${ }^{\mathrm{z}}$ Benomyl $=$ methyl 1-(butylcarbamoyl)-2-benzimidazolecarbamate, carbendazim $=$ methyl 2-benzimidazolecarbamate, thiabendazole $=2$-(4-thiazolyl) benzimidazole, thiophanate methyl $=$ dimethyl 4-4'-o-phenylenebis-3-thioallophanate, etridiazol $=5$ ethoxy-3-trichloromethyl-1,2,4-thiadiazole, metalaxyl $=N$-(2,6-dimethylphenyl)- $N$-(methoxyacetyl)-alanine methyl ester.

${ }^{y}$ Not analyzed for DBU; lot AG29098048 was used only in petunia study 6.

following their standard procedures for DBU analysis (Moye et al., 1994). All fungicides, except Derosal and Mertect 340-F, are labeled for drenches of bedding plants. Derosal and Mertect 340-F were used because of the chemical similarity of their active ingredient to benomyl. Benlate DF and WP were used at $12 \mathrm{~g} \cdot \mathrm{m}^{-2}\left(1.2 \mathrm{~g} \cdot \mathrm{L}^{-1}, 10\right.$ $\mathrm{L} \cdot \mathrm{m}^{-2}$; or $0.01 \mathrm{lb} / \mathrm{gal}, 2$ pints/ft), the maximum labeled drench rate for ornamentals and bedding plants. At this rate, $6.0 \mathrm{~g}$ or $0.022 \mathrm{~mol}$ of benomyl was applied per square meter. Mertect $340-\mathrm{F}$ was used at a rate of $14.3 \mathrm{~g} \cdot \mathrm{m}^{-2}\left(6.0 \mathrm{~g}\right.$ or $0.030 \mathrm{~mol}$ of active ingredient $\left./ \mathrm{m}^{2}\right)$. The fungicide $3336 \mathrm{WP}$ was initially used at $13.7 \mathrm{~g} \cdot \mathrm{m}^{-2}(6 \mathrm{~g}$ a.i., 0.020 $\left.\mathrm{mol} \cdot \mathrm{m}^{-2}\right)$, but later at $14.9 \mathrm{~g} \cdot \mathrm{m}^{-2}\left(0.022 \mathrm{~mol} \cdot \mathrm{m}^{-2}\right)$, because the activity is more closely related to the molar amount of chemical than to the mass. Derosal was always applied at the same molar amount of active ingredient as Benlate DF, $6.7 \mathrm{~g} \cdot \mathrm{m}^{-2}\left(0.022 \mathrm{~mol} \cdot \mathrm{m}^{-2}\right)$. Banrot, a mixture of atriadiazole and thiophanate fungicides, was used at 10.4 $\mathrm{g} \cdot \mathrm{m}^{-2}$. Subdue, an acetanilide, was included in our studies because it is commonly used in conjunction with thiophanates. It was used at the maximum labeled rate of $0.2 \mathrm{~mL} \cdot \mathrm{m}^{-2}$ for seedlings and 0.82 $\mathrm{mL} \cdot \mathrm{m}^{-2}$ for transplants. Fungicide applications to the plants were made only once during an experiment.

Since Benlate DF contains 10\% (w/w) sucrose and $27.6 \%$ insoluble starch, which can be metabolized by plants and microorganisms, equivalent amounts of sucrose and insoluble starch were added to the control treatments. Sucrose and starch were not added to any of the fungicide treatments. Calculations and gas-exchange measurements indicated that metabolism of the sugar and starch was $<3 \%$ of plant metabolism an lasted for about $24 \mathrm{~h}$. All fungicides were received in unopened containers and opened in our laboratory. Samples of the Benlate lots were placed in sealed, desiccated storage at $4{ }^{\circ} \mathrm{C}$ to prevent chemical changes.

Plugs ( $4.4 \mathrm{~cm}^{3}$ root-zone volume) were drenched 20 to $25 \mathrm{~d}$ after seeding, while transplants (50 to $730 \mathrm{~cm}^{3}$ root-zone volume) were drenched 30 to $40 \mathrm{~d}$ after seeding.

Studies on cultural practices. The interaction between cultural practices and fungicide phytotoxicity was studied in growth chambers where environmental conditions could be controlled. A summary of the studies and environmental conditions is given in Table 2. Different lots of Benlate DF were compared in studies 1, 2, 3, 5, and 10 with cucumber and petunia. Different fungicides were compared in studies 4, 6-9, 11-13, and 16-20. These studies included petunia, cucumber, celosia, and impatiens.

Although Benlate DF does not have separate label rates for plugs and transplants, growers are likely to use lower rates on plugs; different rates of Benlate DF were compared on petunia plugs in study $1-3$.
Since developmental stage of the plants may affect their susceptibility to fungicides, we compared the effects of fungicides on petunia plugs to those on transplants (studies 1-4 vs. 10-17).

Container size greatly influences how much fungicide is applied per plant, and different pot sizes were compared in studies 59 for cucumber and studies 10-17 for petunia.

Study 14-15 were used to determine whether relative humidity affects Benlate DF phytotoxicity to petunia, while studies 5-17 were used to determine possible interactions between temperature and phytotoxicity of fungicides.

Greenhouse studies were conducted to compare the phytotoxicity of different fungicides under conditions that more closely resemble the gradual temperature and light changes in commercial greenhouses.

Growth chamber gas exchange measurements. Continuous measurements of crop gas exchange were made with an open system, based on the principles reviewed by Bugbee (1992). Sealed, transparent chambers (DuPont Lucite; $0.47 \mathrm{~m}$ long $\times 0.36$ $\mathrm{m}$ wide $\times 0.61 \mathrm{~m}$ high, $101 \mathrm{~L}$ ) were placed in a growth chamber, and 12 to 60 transplants or 350 seedlings were enclosed in each chamber. Studies 1-16 and 18-20 were conducted in a threechamber system, which included two treatments and a control. Study 17 was conducted in a ten-chamber system, which included four fungicide treatments and a control, each with two replications. Gas exchange in each chamber was measured once every $450 \mathrm{~s}$, for a 15-s period. Daily averages of net photosynthesis during the light period $\left(\mathrm{P}_{\mathrm{net}}\right)$ and respiration during the dark period $\left(\mathrm{R}_{\mathrm{dark}}\right)$ were calculated from these data.

Daily carbon gain $\left(\mathrm{DCG}, \mathrm{mol} \cdot \mathrm{m}^{-2} \cdot \mathrm{d}^{-1}\right)$, gross photosynthesis $\left(\mathrm{P}_{\mathrm{g}}, \mu \mathrm{mol} \cdot \mathrm{m}^{-2} \cdot \mathrm{s}^{-1}\right)$, and carbon use efficiency (CUE, dimensionless), the ratio of $\mathrm{C}$ stored in biomass to total $\mathrm{C}$ fixed in photosynthesis (Yamaguchi, 1978; Amthor, 1989), were determined from the gas exchange data:

$\mathrm{DCG}=\left(\mathrm{LP} \times \mathrm{P}_{\text {net }}+\mathrm{DP} \times \mathrm{R}_{\text {dark }}\right) \times 10^{-6}$

$\mathrm{P}_{\mathrm{g}}=\mathrm{P}_{\text {net }}-\mathrm{R}_{\text {dark }}$

$\mathrm{CUE}=\mathrm{DCG} /\left(\mathrm{LP} \times \mathrm{P}_{\mathrm{g}} \times 10^{-6}\right)$

where LP = light period $(\mathrm{s})$, and DP $=$ dark period $(\mathrm{s})$.

Cumulative carbon gain $\left(\mathrm{CCG}, \mathrm{mol} \cdot \mathrm{m}^{-2}\right)$ was calculated as the integral of DCG over time and is especially useful since it is directly proportional to dry mass (DM) increase. In these equations, it is assumed that $\mathrm{R}_{\mathrm{dark}}$ and the dark respiration during the light period were equal.

Temperature, monitored with shielded, aspirated thermocouples, 
Table 2. Treatments, temperature, and number of plants per chamber in growth chamber trials. Benlate DF lot 311 was used unless otherwise indicated. All studies included at least one control treatment.

\begin{tabular}{|c|c|c|c|c|c|}
\hline Species & $\begin{array}{c}\text { Study } \\
\text { no. }\end{array}$ & Treatment & $\begin{array}{c}\text { Air temp } \\
{ }^{\circ} \mathrm{C} \\
\text { (day/night) }\end{array}$ & $\begin{array}{c}\text { Plant } \\
\text { no. }\end{array}$ & $\begin{array}{c}\text { Container } \\
\text { vol } \\
\left.\text { ( } \mathrm{cm}^{3} / \text { plant }\right)\end{array}$ \\
\hline \multicolumn{6}{|c|}{ Studies with plug flats } \\
\hline \multirow[t]{6}{*}{ Petunia } & 1 & Benlate DF lots 311 and AG29098048 & $30 / 25$ & 350 & 4.4 \\
\hline & 2 & Benlate DF $(0.5 \times)$ lots 311,213 & $30 / 25$ & 350 & 4.4 \\
\hline & 3 & Benlate DF lots 311,193 & $30 / 25$ & 350 & 4.4 \\
\hline & 4 & Subdue & & & \\
\hline & & Banrot & $30 / 25$ & 350 & 4.4 \\
\hline & \multicolumn{5}{|c|}{ Studies with transplants } \\
\hline \multirow[t]{9}{*}{ Cucumber } & 5 & Benlate DF lots 311,193 & $35 / 30$ & 60 & 50 \\
\hline & 6 & Benlate DF & & & \\
\hline & & Subdue & $35 / 30$ & 60 & 50 \\
\hline & 7 & Benlate DF & & & \\
\hline & & Benlate WP & $35 / 30$ & 12 & 730 \\
\hline & 8 & Benlate DF & & & \\
\hline & & Benlate WP & $30 / 27$ & 36 & 170 \\
\hline & 9 & Benlate DF & & & \\
\hline & & Mertect $340 \mathrm{~F}$ & $31 / 25$ & 36 & 170 \\
\hline \multirow[t]{15}{*}{ Petunia } & 10 & Benlate DF lots 311,193 & $30 / 25$ & 36 & 170 \\
\hline & 11 & Benlate DF & & & \\
\hline & & Benlate WP & $35 / 30$ & 36 & 170 \\
\hline & 12 & Benlate DF & & & \\
\hline & & $3336 \mathrm{WP}$ & $30 / 25$ & 60 & 50 \\
\hline & 13 & Benlate DF & & & \\
\hline & & $3336 \mathrm{WP}$ & $30 / 25$ & 60 & 50 \\
\hline & 14 & Benlate DF ( $80 \%$ and $90 \% \mathrm{RH})$ & $30 / 25$ & 60 & 50 \\
\hline & 15 & Benlate DF (60\% and $85 \% \mathrm{RH})$ & $33 / 28$ & 60 & 50 \\
\hline & 16 & Benlate DF & & & \\
\hline & & $3336 \mathrm{WP}$ & $25 / 20$ & 60 & 50 \\
\hline & 17 & Benlate DF & & & \\
\hline & & Derosal & & & \\
\hline & & Subdue & & & \\
\hline & & $3336 \mathrm{WP}$ & $29 / 23$ & 60 & 50 \\
\hline \multirow[t]{4}{*}{ Celosia } & 18 & Benlate & & & \\
\hline & & DF $3336 \mathrm{WP}$ & $35 / 31$ & 60 & 50 \\
\hline & 19 & Benlate DF & & & \\
\hline & & $3336 \mathrm{WP}$ & $35 / 30$ & 60 & 50 \\
\hline \multirow[t]{2}{*}{ Impatiens } & 20 & Benlate DF & & & \\
\hline & & $3336 \mathrm{WP}$ & $32 / 26$ & 60 & 50 \\
\hline
\end{tabular}

was maintained at 25 to $35^{\circ} \mathrm{C}$ day and 20 to $31^{\circ} \mathrm{C}$ night, depending on the study (Table 2). Relative humidity, measured with capacitance-type sensors (Vaisala Sensor Systems, model HMP 35A), was typically $70 \%$ to $80 \%$. Photosynthetic photon flux at the canopy level was between 300 and $500 \mu \mathrm{mol} \cdot \mathrm{m}^{-2} \cdot \mathrm{s}^{-1}$ depending on the study, except for experiment 17 with petunia, when light intensity was $780 \mu \mathrm{mol} \cdot \mathrm{m}^{-2} \cdot \mathrm{s}^{-1}$. Photoperiod was either 14 or $16 \mathrm{~h}$.

Gas-exchange system performance and accuracy were determined by reacting a known amount of $\mathrm{NaHCO}_{3}$ with acid and measuring the evolved $\mathrm{CO}_{2}$. The $\mathrm{CO}_{2}$ recovery of the system was $102 \% \pm 6 \%$ (mean \pm standard deviation).

Greenhouse experiments. A system with 10 identical chambers was used in a greenhouse. The incoming air was enriched with $\mathrm{CO}_{2}$ to keep the $\mathrm{CO}_{2}$ concentration in the chambers at $400 \pm 20$ $\mu \mathrm{mol} \cdot \mathrm{mol}^{-1}$. Flow rates were adjusted to maintain similar $\mathrm{CO}_{2}$ concentrations in all chambers. Samples of pre- and postchamber air were taken with 5-mL syringes. The $\mathrm{CO}_{2}$ concentrations were determined by injecting a 4-mL sample into the $\mathrm{CO}_{2}$-free air stream to the sample cell of an infrared gas analyzer (IRGA) (model 225; ADC), connected to a chart recorder. Peak height was used a to determine $\mathrm{CO}_{2}$ concentrations. A similar technique has been described in detail by Saltveit and Strike (1989). The reference cell of the analyzer was continuously supplied with $\mathrm{CO}_{2}$-free air. The IRGA was calibrated by injecting $4 \mathrm{~mL}$ of a standard gas into the air stream to the reference cell. Net photosynthesis was calculated as explained above. DCG, CCG, and CUE calculations were not possible in the greenhouse, because continuous measurements are needed for these computations. Temperature inside the chambers was maintained between 22 and $35^{\circ} \mathrm{C}$, with the relative humidity between $70 \%$ and $95 \%$. Total daily photon flux was between 25 and $40 \mathrm{~mol} \cdot \mathrm{m}^{-2} \cdot \mathrm{d}^{-1}$. Three studies with impatiens and one study with petunia were conducted in the greenhouse.

Whole-plant measurements. Shoot DM was determined at the end of the experiments ( 11 to $24 \mathrm{~d}$ after treatment), after drying the plant material at $80{ }^{\circ} \mathrm{C}$ to a constant mass. Total $\mathrm{N}$ in shoots was determined with a CHN-analyzer (model CHN-1000; LECO). 
Table 3. Growth chamber trials. The effect of different fungicides on the cumulative carbon gain (CCG), shoot dry mass (DM), and net photosynthesis $\left(\mathrm{P}_{\text {net }}\right)$ at 1,2, or $7 \mathrm{~d}$ after drench. Data are expressed as a percentage of untreated control plants \pm standard error among studies. Plug flat trials are not included in these means. Note the good correlation between CCG and shoot DM in all but the Benlate treatments. Benlate-treated plants probably had smaller root systems, causing a discrepancy between CCG and shoot DM (see text).

\begin{tabular}{|c|c|c|c|c|c|c|c|}
\hline \multirow[b]{2}{*}{ Crop } & \multirow[b]{2}{*}{ Fungicide } & \multirow[b]{2}{*}{$\mathrm{n}$} & \multirow{2}{*}{$\begin{array}{l}\text { Cumulative } \\
\text { carbon gain }\end{array}$} & \multirow{2}{*}{$\begin{array}{c}\text { Shoot } \\
\text { DM }\end{array}$} & \multicolumn{3}{|c|}{$\mathrm{P}_{\text {net }}$} \\
\hline & & & & & Day 1 & Day 2 & Day 7 \\
\hline \multicolumn{8}{|c|}{ Percent of control plants } \\
\hline \multirow[t]{2}{*}{ Celosia } & Benlate DF 311 & 2 & $63.0 \pm 19.6$ & $--^{\mathrm{z}}$ & $42.0 \pm 1.8$ & $67.4 \pm 3.8$ & $75.5 \pm 9.3$ \\
\hline & $3336 \mathrm{WP}$ & 2 & $81.8 \pm 1.8$ & --- & $81.6 \pm 11.5$ & $81.8 \pm 0.1$ & $79.5 \pm 0.6$ \\
\hline \multirow[t]{5}{*}{ Cucumber } & Benlate DF 311 & 5 & $80.1 \pm 3.1$ & --- & $72.5 \pm 2.4$ & $83.1 \pm 4.1$ & $93.1 \pm 6.5$ \\
\hline & Benlate DF 193 & 1 & 68.5 & --- & 57.1 & 69.2 & 87.5 \\
\hline & Benlate WP & 2 & $76.2 \pm 2.5$ & --- & $79.0 \pm 8.1$ & $83.8 \pm 1.1$ & $83.0 \pm 2.1$ \\
\hline & Mertect 340-F & 1 & -5.3 & --- & -1.0 & -2.2 & -5.8 \\
\hline & Subdue & 1 & 106.9 & --- & 107.9 & 108.9 & 102.3 \\
\hline \multirow[t]{2}{*}{ Impatiens } & Benlate DF 311 & 1 & 79.0 & 100.1 & 25.5 & 34.7 & 92.4 \\
\hline & $3336 \mathrm{WP}$ & 1 & 68.0 & 89.7 & 86.1 & 78.2 & 56.7 \\
\hline \multirow[t]{6}{*}{ Petunia } & Benlate DF 311 & 11 & $83.5 \pm 2.8$ & $103.2 \pm 2.6^{\mathrm{y}}$ & $77.2 \pm 3.9$ & $75.6 \pm 2.1$ & $89.1 \pm 3.4$ \\
\hline & Benlate DF 193 & 1 & 88.4 & 86.1 & 63.7 & 80.0 & 102.9 \\
\hline & Benlate WP & 1 & 75.5 & 78.5 & 61.7 & 76.3 & 62.3 \\
\hline & Derosal & 2 & $110.0 \pm 2.1$ & $110.4 \pm 0.9$ & $103.4 \pm 2.3$ & $106.4 \pm 1.1$ & $110.2 \pm 2.5$ \\
\hline & $3336 \mathrm{WP}$ & 5 & $96.3 \pm 4.1$ & $97.9 \pm 4.1^{\mathrm{x}}$ & $101.9 \pm 3.5$ & $100.7 \pm 4.2$ & $94.4 \pm 5.5$ \\
\hline & Subdue & 2 & $102.8 \pm 0.8$ & $100.6 \pm 3.5$ & $102.0 \pm 0.6$ & $99.4 \pm 0.8$ & $103.0 \pm 1.6$ \\
\hline
\end{tabular}

${ }^{\mathrm{z}}$ Data not collected.

yean of 10 measurements.

${ }^{\mathrm{x}}$ Mean of four measurements.

Nitrate was analyzed using $\mathrm{Ca}(\mathrm{OH})_{2}$ extractant and chromotropic acid color development. Color intensity was measured with a spectrophotometer (Spectronic 1001; Bausch \& Lomb). Reduced $\mathrm{N}$ was calculated as the difference between total $\mathrm{N}$ and nitrate. Calcium, K, P, and S were measured with an inductively-coupled plasma spectrometer (ICAP 9000; Thermo-Jarrel Ash).

\section{Results}

Gas exchange. Table 3 summarizes the results from the 20 growth chamber studies, while data from the most comprehensive study (study 17 with petunia) are shown in Figs. 1 and 2. Treatment effects in study 17 were less than average (compare Figs. 1 and 2 to Table 3). Benlate DF drenches typically resulted in an initial decrease in $\mathrm{P}_{\text {net }}$ (Fig. 1, Table 3). This effect was generally greatest at 1 to $2 \mathrm{~d}$ after the treatment, after which the plants slowly recovered (Table 3). Results were similar in the greenhouse experiments (Fig. 3). In addition to reducing net photosynthesis, Benlate DF also reduced CUE for a 3-d period after the drench. Derosal, 3336 WP, and Subdue slightly increased CUE (Fig. 2 A and B). The combination of reduced photosynthesis and CUE by Benlate DF resulted in a decrease in DCG for a period of 7 to 10 $\mathrm{d}$ after the drench application (Fig. $2 \mathrm{C}$ and D). Because of the initial reduction in DCG, CCG never recovered to the control level (Fig. 2 E and F, Table 3). Benlate DF and Benlate WP responses were similar during the first few days after treatment, but Benlate WP drenches resulted in a larger decrease in $\mathrm{P}_{\text {net }} 7 \mathrm{~d}$ after treatment (Table 3, Fig 3). Higher relative humidity ( $85 \%$ to $90 \%$ ) caused a larger decrease in CCG $(25 \%)$ than the treatment at lower humidity (60\% to $80 \%$ ), which caused a $13 \%$ decrease CCG. Temperature did not appear to have an important influence on the phytotoxicity of Benlate DF.

Benlate DF was more phytotoxic to petunia seedlings in plug flats $\left(4.4 \mathrm{~cm}^{3}\right.$ root-zone volume) than to older, transplanted plants (50 $\mathrm{cm}^{3}$ root-zone volume). Net photosynthesis of petunia seedlings $24 \mathrm{~h}$ after the drench was reduced by $57 \%$ in petunia study 1 and by $25 \%$ to $35 \%$ in petunia study 3 (Fig. 4). Petunia study 2 was conducted at half the maximum label rate $\left(5 \mathrm{~L} \cdot \mathrm{m}^{-2}\right.$ or $\left.1 \mathrm{pt} / \mathrm{ft}^{2}\right)$ and both Benlate DF lots decreased net photosynthesis by $18 \%$, which was about half of the decrease observed at the $1 \times$ drench rate. The photosynthetic rate of Benlate treated plug flats had not recovered at the end of any of the studies (Fig. 4), although the plants produced normal leaves in the greenhouse about $20 \mathrm{~d}$ after the Benlate DF application. Banrot and Subdue did not significantly affect petunia plugs, with average photosynthetic rates of $91 \%$ and $110 \%$ of the control, respectively (petunia study 4$)$. These differences in photosynthesis were the result of small differences in initial plant size; photosynthetic rate before and after the fungicide

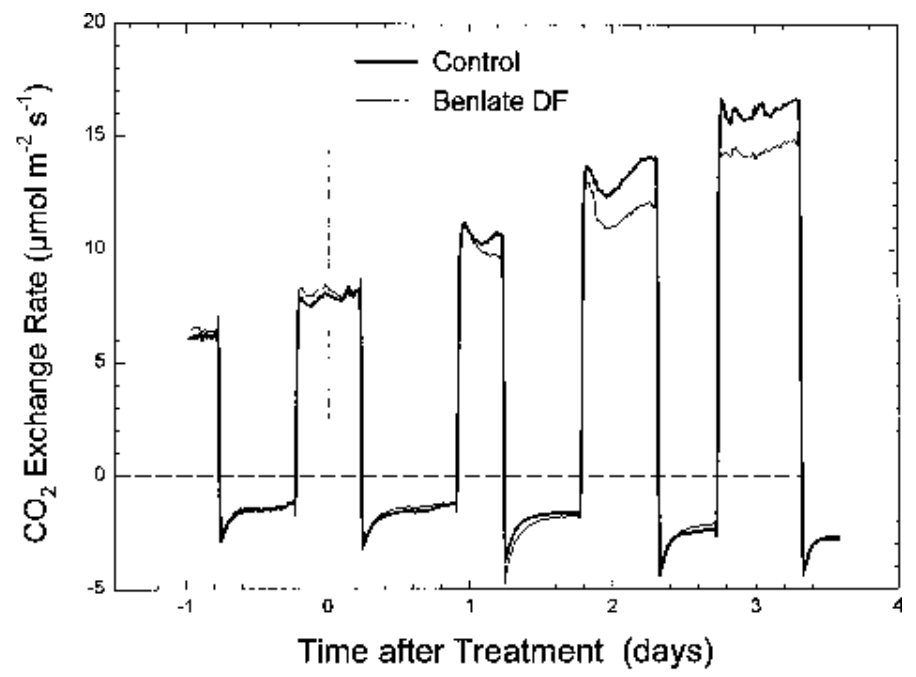

Fig. 1. An example of the time course for the effect of Benlate DF on net photosynthesis and dark respiration of petunia (study 17). Plants were treated with the maximum labeled drench rate of Benlate DF $\left(12 \mathrm{~g} \cdot \mathrm{m}^{-2}\right)$. Data represent the mean of two gas-exchange chambers with 60 plants in each chamber. Benlate DF effects on gas exchange were smaller than those in comparable studies. 
drench was changed by $<4 \%$ in both treatments. Increased rooting volume appeared to aggravate Benlate DF damage in cucumber. Benlate DF reduced CCG by $11 \%, 16 \%$, and $26 \%$ with rooting volumes of 50,170 and $730 \mathrm{~cm}^{3}$, respectively. We did not see a similar correlation with transplanted petunia, where Benlate DF reduced CCG by about $16 \%$, regardless of rooting volume.

3336 WP decreased net photosynthesis of celosia and impatiens but had little effect on petunia (Table 3 ). The effect was different from that of Benlate DF. The initial decrease in net photosynthesis was usually small but became more pronounced over time (Table 3 and Fig. 3). In experiments where 3336 WP decreased $P_{n e t}$, the plants did not recover within 2 weeks after the drench. This suggests that the mode of photosynthesis inhibition is different for $3336 \mathrm{WP}$ and Benlate DF.

Mertect 340-F was extremely phytotoxic to cucumber, but is not labeled for a drench treatment. Gross photosynthesis was less than the respiration rate, resulting in a negative $\mathrm{P}_{\text {net }}$ (Table 3 ). In preliminary studies, Mertect 340-F had similar effects on petunia and impatiens and was therefore not included in other studies. Subdue did not significantly affect the photosynthetic rate of transplanted petunia or cucumber, while Derosal had either no or a small stimulating effect on $\mathrm{P}_{\text {net }}$ of petunia.

Fungicide treatments altered CCG of all species examined. Mertect 340-F, Benlate WP, and Benlate DF consistently decreased CCG. 3336 WP decreased CCG of celosia and impatiens but did not affect CCG of petunia, while Derosal and Subdue slightly increased CCG of petunia. Differences in CCG were

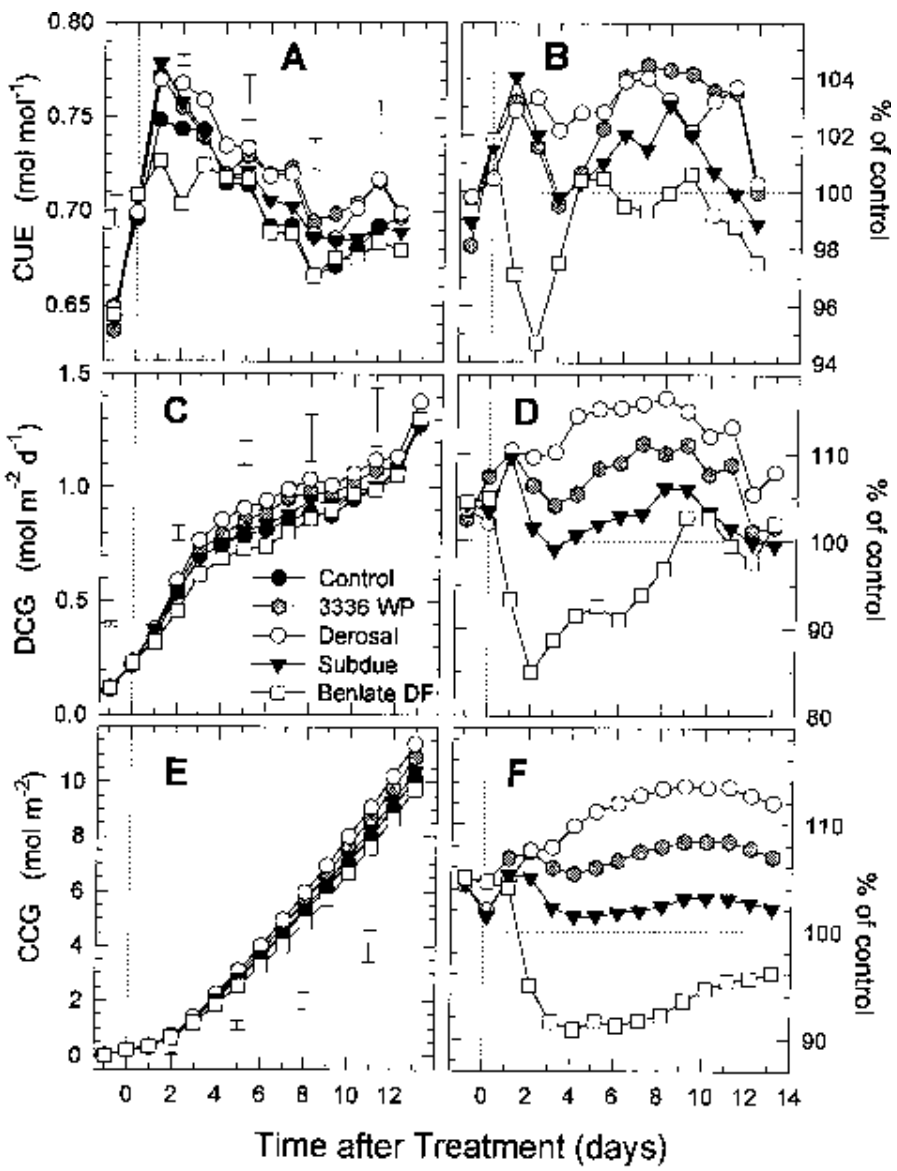

Fig. 2. Carbon use efficiency (CUE), daily carbon gain (DCG), and cumulative carbon gain (CCG) of petunia (study 17) as affected by four fungicides. Data represent the mean of two gas-exchange chambers with 60 plants each. Both absolute values $(\mathbf{A}, \mathbf{C}, \mathbf{E})$ and data expressed as a percentage of the control plants $(\mathbf{B}, \mathbf{D}, \mathbf{F})$ are shown. Error bars represent selected $\mathrm{LSD}_{0.05} \mathrm{~S}$. reflected in shoot DM accumulation, except when Benlate DF was used (Table 3; see discussion).

Although CCG calculations were not possible in the greenhouse studies, there was a correlation between $3336 \mathrm{WP}$ effects on photosynthesis and shoot DM. 3336-WP treated plants had lower shoot DM in two out of three impatiens studies. The first study (Fig. 3A) was probably too short to detect any effects of $3336 \mathrm{WP}$ on photosynthesis or shoot DM of impatiens. As in the growth chamber studies, Benlate decreased photosynthesis in the greenhouse (Fig. 3), but these differences were generally not reflected in shoot DM (Table 4).

Nutrient composition. Fungicide effects on the concentration of nutrients in study 17 are shown in Table 5. Benlate DF increased the total concentration of $\mathrm{N}$ in the plants but not the concentration of reduced $\mathrm{N}$. Differences in $\mathrm{N}$ levels were caused by nitrate concentrations in the plants. Calcium levels were reduced by Benlate DF and Derosal but not by the similar fungicide 3336 WP. Benlate DF reduced Ca levels in five out of six experiments where nutrients were analyzed, while Derosal decreased Ca in three out
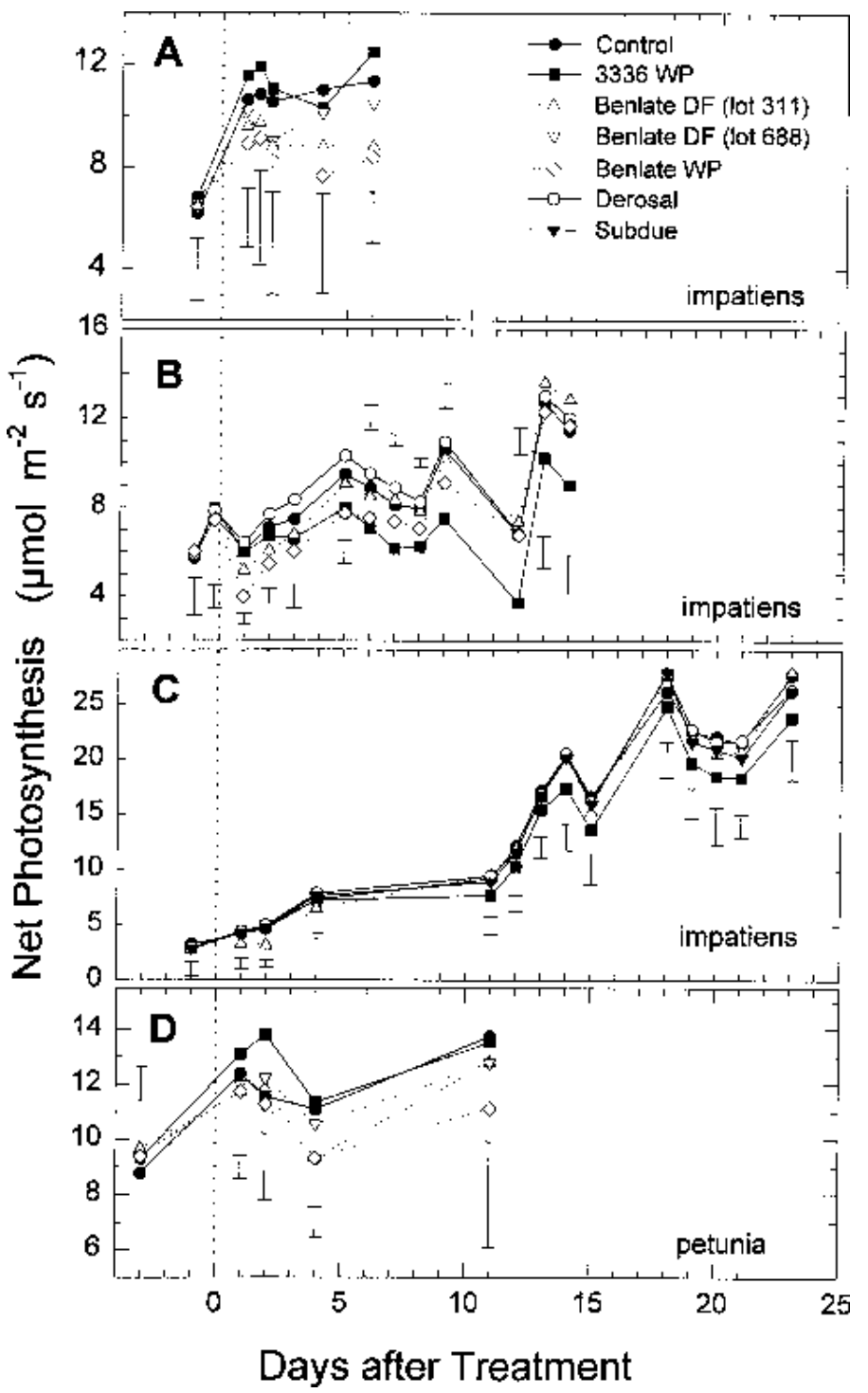

Fig. 3. The effect of different fungicides on the net photosynthesis of impatiens (AC) and petunia (D) under greenhouse conditions. Data represent the mean of two gas-exchange chambers with 60 plants each. Error bars represent $\operatorname{LSD}_{0.05}$. Note: only five of the seven treatments in the legend (A) were used in each individual study. 


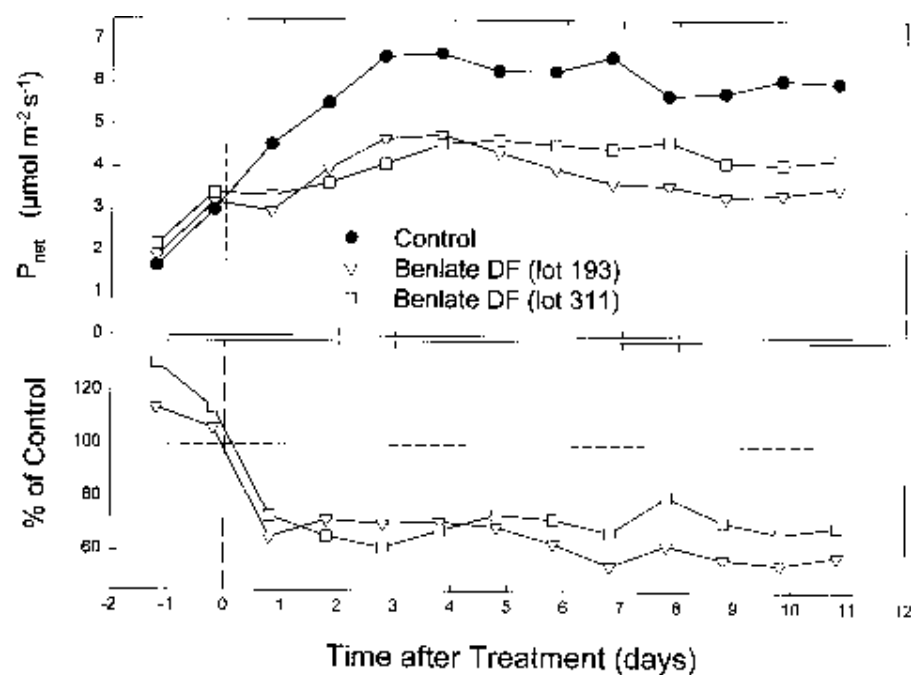

Fig. 4. The effect of two different Benlate DF lots on net photosynthesis of petunia seedlings (study 3$)$. Plants were drenched with a $1 \times$ rate $\left(10 \mathrm{~L} \cdot \mathrm{m}^{-2}\right.$ of fungicide solution with $1.2 \mathrm{~g} \cdot \mathrm{L}^{-1}$ of Benlate DF). Data were collected in gas-exchange chambers with 350 plants/chamber. Both absolute values (A) and data expressed as a percentage of the control plants $(\mathbf{B})$ are shown.

of four trials. Potassium, $\mathrm{P}$, and $\mathrm{S}$ levels were sometimes affected by the fungicide treatments, but these effects were not consistent among studies. Benlate DF and WP had similar effects on nutrient levels (results not shown).

Visual symptoms: petunias. There were no phytotoxic visual symptoms associated with Subdue or Banrot drenches. Benlate DF often caused chlorotic or necrotic leaf edges, leaf deformation, or interveinal chlorosis in petunia. Chlorosis normally started about $3 \mathrm{~d}$ after the drench in the young leaves, while leaves that started expanding about 1 week after the fungicide drench often looked healthy. 3336 WP and Derosal sometimes also caused chlorosis in petunia, but the symptoms were less pronounced than with Benlate DF. The visual effects of Benlate DF on plugs were much more severe than on transplants. Plugs became extremely chlorotic, but like transplants, seedlings eventually produced healthy looking new leaves.

Visual symptoms: other species. The visual effects of $3336 \mathrm{WP}$ were most pronounced in impatiens. Leaf tips became chlorotic and chlorosis slowly spread around the leaf edges of the plants. Benlate DF sometimes caused leaf tip necrosis and interveinal chlorosis. Benlate DF also caused necrotic spots on the leaves of celosia in one of the two experiments and resulted in chlorosis of cucumber leaves. Mertect 340-F caused chlorosis in cucumber starting $4 \mathrm{~d}$ after treatment, and the plants eventually died.

Development. Benlate DF delayed flowering by 2 to $3 \mathrm{~d}$ in petunia and impatiens. Celosia plants were already flowering at the start of the trials, so fungicide effects on flowering could not be determined. None of the other fungicides delayed flowering.

\section{Discussion}

Benlate DF and WP drenches decreased net photosynthesis by an average of $20 \%$ to $30 \%$ for about 1 week following treatment. This may partly be caused by benomyl breakdown and the subsequent formation of dibutylurea (DBU). Unopened boxes of Benlate DF and WP often contain DBU, while additional DBU can be formed on wet plant surfaces after application (Moye et al., 1994). Aqueous solutions of Benlate can produce $n$-butyl isocyanate (BIC) (Tang et al., 1992, 1993), which can subsequently react to produce DBU (Moye et al., 1994). Dibutylurea completely inhibits photosynthesis of hydrilla (Shilling et al., 1994) and also inhibits the photosynthesis of petunia and impatiens (van Iersel and Bugbee, unpublished data). The mode of action of DBU appears to be similar to that of the substituted urea herbicide diuron, a photosystem II inhibitor (Shilling et al., 1994). This agrees with the finding that benomyl can inhibit the Hill reaction in isolated chloroplasts (Kristeva and Kristev, 1971). Previous reports on the effect of Benlate on $\mathrm{P}_{\text {net }}$ are inconsistent. Ferree and Hall (1975) did not see any effect of Benlate on the gas exchange of apple leaves, while Stamps and Chase (1988) saw a $10 \%$ to $14 \%$ decrease in $\mathrm{P}_{\text {net }}$ of leatherleaf fern after Benlate WP sprays, but the differences were not statistically significant. Wood et al. (1984) found a $25 \%$ decrease in $\mathrm{P}_{\text {net }}$ of pecan after a single foliar application of Benlate WP. The differences between these previous studies may be due to differences between production lots of Benlate. We found similar effects of the different Benlate DF production lots, but all of the lots were low in DBU (Table 1).

There have been no published reports of the effects of DBU on the gas exchange of higher plants, but DBU decreased the dry matter production and shoot height of cucumber (Shilling et al., 1994). This corroborates reports that Benlate DF can decrease the mass of a variety of species (Cole et al., 1970; Ishii, 1973; Reyes, 1975; Rouchaud et al., 1985; Schreiber and Hock, 1975). Wensley (1972) and Wensley and Huang (1970) report that benomyl suppresses growth of muskmelon for 12 to $14 \mathrm{~d}$, but that plants recover eventually. This agrees with our finding that Benlate DF causes a temporary decrease in $\mathrm{P}_{\text {net }}$.

Our studies did not indicate large interactions between temperature and Benlate phytotoxicity. Benlate DF decreased $\mathrm{P}_{\text {net }}$ in all environments tested. The reduction in $\mathrm{P}_{\text {net }}$ increased with humidity, and CCG was reduced by $25 \%$ at $85 \%$ to $90 \% \mathrm{RH}$, and by only $13 \%$ with lower RH (studies 14 and 15).

Benomyl and MBC are taken up passively by the roots, transported apoplastically, and accumulate in leaf tips and margins (Peterson and Edgington, 1970). Based on this, it would be expected that higher accumulation of phytotoxic compounds would occur under conditions of high evaporative demand. However, CCG of Benlate DF-treated plants was higher at low humidity than that at high humidity. It is possible that the lower CCG at high humidity was caused by a direct effect of the humidity on the growth rate of the plants.

Since the ratio between the amount of applied fungicide and rooting volume is higher for seedlings $\left(4.4 \mathrm{~cm}^{3}\right.$ root volume $)$ than for transplanted plants ( 50 to $200 \mathrm{~cm}^{3}$ root volume), it is likely that seedlings can accumulate higher concentrations of benomyl and/

Table 4. The effect of different fungicides on the shoot dry mass (DM) of impatiens and petunia. Data were collected in four separate greenhouse experiments.

\begin{tabular}{llclc}
\hline & \multicolumn{4}{c}{ Shoot DM (g/plant) } \\
\cline { 2 - 5 } Fungicide & \multicolumn{3}{c}{ Impatiens } & Petunia \\
\hline Control & $0.20 \mathrm{a}^{\mathrm{z}}$ & $0.44 \mathrm{ab}$ & $0.48 \mathrm{a}$ & $0.40 \mathrm{a}$ \\
Benlate DF (311) & $0.18 \mathrm{a}$ & $0.46 \mathrm{a}$ & $0.45 \mathrm{~b}$ & $0.38 \mathrm{ab}$ \\
Benlate DF (688) & $0.19 \mathrm{a}$ & --- & --- & $0.38 \mathrm{ab}$ \\
Benlate WP & $0.17 \mathrm{a}$ & $0.44 \mathrm{ab}$ & --- & $0.35 \mathrm{~b}$ \\
3336 WP & $0.20 \mathrm{a}$ & $0.41 \mathrm{~b}$ & $0.42 \mathrm{c}$ & $0.36 \mathrm{ab}$ \\
Derosal & --- & $0.47 \mathrm{a}$ & $0.44 \mathrm{~b}$ & --- \\
Subdue & --- & --- & $0.45 \mathrm{ab}$ & ---
\end{tabular}

${ }^{\mathrm{z}}$ Means within a column followed by the same letter are not significantly different $(P=0.05)$. 
Table 5. The effect of fungicide drenches on the nutrient composition of petunia in growth chambers. Data are from petunia study 17.

\begin{tabular}{lccccccc}
\hline \hline Treatment & Total N & Nitrate & Reduced N & Ca & K & P & S \\
\hline & & & & $\%$ & & & \\
Control & $2.58 \mathrm{~b}^{\mathrm{z}}$ & $0.15 \mathrm{~b}$ & $2.42 \mathrm{a}$ & $0.74 \mathrm{a}$ & $4.70 \mathrm{ab}$ & $0.52 \mathrm{a}$ & $0.28 \mathrm{a}$ \\
BenlateDF & $2.86 \mathrm{a}$ & $0.36 \mathrm{a}$ & $2.51 \mathrm{a}$ & $0.58 \mathrm{~b}$ & $4.98 \mathrm{a}$ & $0.52 \mathrm{a}$ & $0.28 \mathrm{a}$ \\
Subdue & $2.54 \mathrm{~b}$ & $0.20 \mathrm{~b}$ & $2.34 \mathrm{a}$ & $0.73 \mathrm{a}$ & $4.96 \mathrm{a}$ & $0.52 \mathrm{a}$ & $0.26 \mathrm{~b}$ \\
3336 WP & $2.55 \mathrm{~b}$ & $0.20 \mathrm{~b}$ & $2.35 \mathrm{a}$ & $0.74 \mathrm{a}$ & $4.49 \mathrm{~b}$ & $0.51 \mathrm{a}$ & $0.29 \mathrm{a}$ \\
Derosal & $2.53 \mathrm{~b}$ & $0.17 \mathrm{~b}$ & $2.36 \mathrm{a}$ & $0.62 \mathrm{~b}$ & $4.44 \mathrm{~b}$ & $0.50 \mathrm{a}$ & $0.24 \mathrm{~b}$ \\
\hline
\end{tabular}

${ }_{\mathrm{z}}$ Means within a column followed by the same letter are not significantly different $(P=0.05)$.

or its breakdown products in their leaves. This could explain the more pronounced effect of benomyl on seedlings as compared to transplants. Since benomyl and MBC are not phloem-mobile (Peterson and Edgington, 1970), it is unlikely that they are redistributed within plants. Benomyl is relatively immobile in soil (Baude et al., 1974; Johnson and Lavy, 1994; Rhodes and Long, 1974) and uptake is reduced by organic matter in the planting medium (Schreiber et al., 1971). Benomyl that is not rapidly taken up by plants may thus become unavailable to the plants. Immobility of benomyl and MBC in plants and soils may prevent accumulation in leaves that expand several days after treatment. These leaves are therefore not expected to show phytotoxicity. New leaves generally appeared healthy and were probably essential in the recovery of $P_{\text {net }}$ after the drench.

Differences in CCG between controls and Benlate DF treated plants were not reflected in shoot DM, but there was a close correlation between CCG and shoot DM for the other fungicides (Table 3). Since CCG integrates carbon gain in the roots and shoots together, the lower CCG and similar shoot mass of Benlate-treated plants suggests that these plants had a smaller root mass than control plants. For example, based on CCG and shoot DM data from study 17 with petunia, Benlate DF treated plants would be expected to have a root DM of $0.053 \mathrm{~g} / \mathrm{plant}$, compared to $0.112 \mathrm{~g}$ for control plants. Estimated root DM in the other treatments varied from $0.129 \mathrm{~g}$ to $0.105 \mathrm{~g} / \mathrm{plant}$.

Benomyl indeed has been shown to affect root growth and development. Hocking and Thomas (1979) showed that it suppresses adventitious root development of cuttings and severely reduced root quality and dry weights. Root dry weight of Chrysanthemum morifolum and Choysia ternata cuttings was reduced up to $40 \%$, depending on the Benomyl concentration. Benomyl also can inhibit rooting of poinsettia (Euphorbia pulcherrima Willd.) cuttings (Lee et al., 1983), while benzimidazole reduced root elongation of cucumber (Klingensmith, 1961). Benomyl interferes with cell division of root tip cells of cucumber (Woo and Wick, 1995) and onion (Richmond and Phillips, 1975). Aragaki et al. (1994) showed that a volatile component of Benlate suspensions (probably BIC) can inhibit root growth of cucumber. Benlate inhibition of root growth could also be the result of the breakdown product $n$-butylamine, which can reduce root growth of Hyoscyamus albus and Datura stramonium (Hibi et al., 1992).

Benomyl significantly altered nutrient composition of tomato, depending on the $\mathrm{NH}_{4}^{+} / \mathrm{NO}_{3}{ }^{-}$ratio in the nutrient solution (Somda et al., 1990). Calcium levels were doubled by a benomyl treatment with $\mathrm{NH}_{4}^{+}$as the sole $\mathrm{N}$ source, halved with a 1:1 ratio, and not affected with $\mathrm{NO}_{3}{ }^{-}$as the sole $\mathrm{N}$ source. Effects on other cations $(\mathrm{K}$, $\mathrm{Mg}, \mathrm{Fe}, \mathrm{Zn}, \mathrm{Mn}, \mathrm{Cu}$, and $\mathrm{Mo}$ ) were similar, indicating that benomyl may stimulate cation uptake when $\mathrm{NH}_{4}^{+}$is used as an $\mathrm{N}$ source, but inhibit uptake, when $\mathrm{NH}_{4}{ }^{+}$and $\mathrm{NO}_{3}{ }^{-}$are present in equal amounts. The $\mathrm{NH}_{4}^{+} / \mathrm{NO}_{3}{ }^{-}$ratio in our nutrient solution was 2:7. Benlate effects in our experiments would thus be expected to be intermediate between the 1:1 and 0:1 ratios in Somda et al. (1990).
This was indeed the case for $\mathrm{Ca}$ ( $22 \%$ decrease), but we did not see consistent effects on other cations.

The interaction between nutrient levels and $\mathrm{N}$ source of the nutrient solution may be related to the effects of Benlate on nitrification. Nitrification can be stimulated (van Faassen, 1974) or inhibited by Benlate, while Derosal does not affect nitrification (Ramakrishna et al., 1979). The reason for the different effects of Benlate on nitrification may depend on soil properties and experimental conditions (Ramakrishna et al., 1979). Nitrification processes were not studied in our experiments, but could explain the nitrate accumulation occurring in Benlate-treated plants. A decrease in $\mathrm{Ca}, \mathrm{Mn}$, and $\mathrm{Na}$ and an increase in $\mathrm{Fe}$ and $\mathrm{Al}$ as the result of benomyl applications was seen in cucumber (Cole et al., 1970). Machado-Neto et al. (1994) suggested that benomyl may interfere with nutrient uptake by inhibiting the establishment of mycorrhizae on roots. Benlate DF decreased Ca levels in five out of six of our studies, but effects on other nutrients were variable. Benlate effects on nutrient composition may depend on interactions between growing medium, nutrient availability, and soil microbes.

Visual symptoms of Benlate phytotoxicity were similar to those previously reported. Marginal chlorosis as the result of Benlate applications has been observed in cucumber, Cassia occidentalis, crucifers, muskmelon, and pumpkin (Delp and Klopping, 1968; Hammett, 1968; Ishii, 1973, Reyes, 1975; Schroeder and Provvidenti, 1968; Van Assche and Vanachter, 1970; Wensley, 1972). A literature search revealed little information on possible phytotoxicity of the other fungicides used in our studies. Severe phytotoxicity (marginal chlorosis, necrosis, and inhibited root growth) occurred on azaleas drenched multiple times with an experimental fungicide (CGA-48988 (50WP)) with the same active ingredient as Subdue (Benson, 1979). However, rates in these experiments were about 10 times as much active ingredient as the maximum labeled rate of Subdue, and the experimental fungicide may have contained different inactive ingredients than Subdue. Banrot decreased the growth of douglas fir [Pseudotsuga menziesii var. glauca (Beissn.) Franco] seedlings (Dumroese et al., 1990). Two thiophanate fungicides caused marginal chlorosis in cucumber (Van Assche and Vanachter, 1970). Apoplastically transported compounds accumulate in leaf margins, where symptoms would be expected to be most severe.

\section{Literature Cited}

Aragaki, M., J.Y. Uchida, and C.Y. Kadooka. 1994. Toxicity of Benlate to cucumber and evidence for a volatile decomposition product. Arch. Environ. Contam. Toxicol. 27:121-125.

Amthor, J.S. 1989. Respiration and crop productivity. Springer-Verlag, New York.

Baude, F.J., H.L. Pease, and R.F. Holt. 1974. Fate of benomyl on field soil and turf. J. Agr. Food Chem. 22:413-418.

Baxter, L.W., W. Witcher, and M.G. Owens. 1975. Benomyl injury to Swedish ivy (Plectranthus australis). Plant Dis. Rpt. 59: 868.

Benson, D.M. 1979. Efficacy and in vitro activity of two systemic 
acylalanines and ethazole for control of phytophtora cinnamomi root rot of azalea. Phytopathology 69:174-178.

Bugbee, B. 1992. Steady-state canopy gas exchange: system design and operation. HortScience 27:770-776.

Cole, H., J.S. Boyle, and C.B. Smith. 1970. Effect of benomyl and certain cucumber viruses on growth, powdery mildew, and element accumulation by cucumber plants in the greenhouse. Plant Dis. Rpt. 54:141-145.

Delp, C.J. 1987. Benzimidazole and related fungicides, p. 233-244. In: H. Lyr (ed.). Modern selective fungicides-properties, applications, methods of action. Longman, New York.

Delp, C.J. and Klopping, H.L. 1968. Performance attributes of a new fungicide and mite ovicide candidate. Plant Dis. Rpt. 52:95-99.

Dumroese, R.K., R.L. James, and D.L. Wenny. 1990. Trial of a granular etridiazole and thiophanate-methylmixture to control Fusarium root disease of container grown Douglas-fir seedlings. New For. 4:231-236.

Ferree, D.C. and F.R. Hall. 1975. Influence of benomyl and oil on photosynthesis of apple leaves. HortScience 10:128-129.

Hammett, K.R.W. 1968. Root applications of a systemic fungicide for control of powdery mildews. Plant Dis. Rpt. 52:754-758.

Hibi, H., T. Fujita, M. Hatano, T. Hahimoto, and Y. Yamada. 1992. Putrescine $N$-methyl transferase in cultured roots of Hyoscyamus albus. $n$-Butylamine as a potent inhibitor of the transferase both in vitro and in vivo. Plant Physiol. 100:826-835.

Hocking, P.J. and M.B. Thomas. 1979. Effect of IBA in combination with thiram, captan, and benomyl on the rooting of four ornamental species. N.Z. J. Expt. Agr. 7:263-296.

Ishii, M. 1973. Control of powdery mildew of cassia occidentalis in relation to bioassay of cymbidium mosaic virus. Plant Dis. Rpt. 57:475477 .

Johnson, W.G. and T.L. Lavy. 1994. In-situ dissipation of benomyl, carbofuran, and triclopyr at three soil depths. J. Environ. Qual. 23:556562.

Klingensmith, M.J. 1961. The effect of certain benzazole compounds on plant growth and development. Amer. J. Bot. 48:40-45.

Kristeva, M. And K. Kristev. 1971. Respiratory and photosynthetic rates in apple leaves treated with the systemic fungicide benomyl. Acta Phytopath. Acad. Sci. Hung. 6:365-369.

Lee, L.W., K.C. Sanderson, and J.G. Williams. 1983. Effect of fungicides applied to polyurethane propagation blocks on rooting of poinsettia cuttings. HortScience 18:359-360.

Machado-Neto, J.G., J.O. Machado, M. Barreto, L.A. Palladini, and M.B. Matallo. 1994. Effect of benomyl on the formation of mycorrhiza in roots of tomato (Lycopersicon esculentum Mill.) seedlings. Bul. Environ. Contam. Toxicol. 52:864-870.

Mihuta-Grimm, L., W.A Erb, and R.C. Rowe. 1990. Fusarium crown and root rot of tomato in greenhouse rock wool systems: Sources of inoculum and disease management with benomyl. Plant Dis. 74:996-1002.

Moye, H.A., D.G. Schilling, H.C. Aldrich, J.E. Gander, M. Buszko, J.P. Toth, W.S. Brey, B. Bechtel, and J.K. Tolson. 1994. N, N'-dibutylurea from $n$-butyl isocyanate, a degradation product of benomyl. 1. Formation in Benlate formulations and on plants. J. Agr. Food Chem. 42:12041208.

Peterson, C.A. and L.V. Edgington. 1970. Transport of the systemic fungicide, benomyl, in bean plants. Phytopathology 60:475-478.

Ramakrishna, C., T.K.S. Gowda, and N. Sethunathan. 1979. Effect of benomyl and its hydrolysis products, $\mathrm{MBC}$ and $\mathrm{AB}$, on nitrification in a flooded soil. Bul. Environ. Contam. Toxicol. 21:328-333.

Reyes, A.A. 1975. Phytotoxicity of benomyl to crucifers. Phytopathology 65:535-539.

Rhodes, R.C. and J.D. Long. 1974. Run-off and mobility studies on benomyl in soils and turf. Bul. Environ. Contam. Toxicol. 12:385-393.

Richmond D.V. and A. Phillips. 1975. The effect of benomyl and carbendazim on mitosis in hyphae of Botrytis cinerea Pers. ex Fr. and roots of Allium cepa L. Pest. Biochem. Physiol. 5:367-379.

Rouchaud, J., C. Moons, and J.A. Meyer. 1985. The effects of herbicide and fungicide treatments on the growth and provitamin A content of lettuce. Pesticide Sci. 16:88-92.

Saltveit, M.E. and T. Strike. 1989. A rapid method for accurately measuring oxygen concentrations in milliliter gas samples. HortScience 24:145147.

Schreiber, L.R. and W.K. Hock. 1975. Effects of benomyl and thiabendazole on growth of several plant species. J. Amer. Soc. Sci. 100:309-313.

Schreiber, L.R., W.K. Hock, and B.R. Roberts. 1971. Influence of planting media and soil sterilization on the uptake of benomyl by American elm seedlings. Phytopathology 61:1512-1515.

Schroeder, W.T. and R. Provvidenti. 1968. Systemic control of powdery mildew on cucurbits with fungicide 1991 applied as soil drenches and seed treatments. Plant Dis. Rpt. 52:630-632.

Shilling, D.G., H.C. Aldrich, H.A. Moye, J.F. Gaffney, J.K. Tolson, R. Querns, M.A. Mossler, and B.L. Russell. 1994. N,N'-dibutylurea from $n$-butyl isocyanate, a degradation product of benomyl. 2. Effects on plant growth and physiology. J. Agr. Food Chem. 42:1209-1212.

Skene, K.G.M. 1972. Cytokinin-like properties of the systemic fungicide benomyl. J. Hort. Sci. 47:179-182.

Somda, Z.C., H.A. Mills, and S.C. Phatak. 1990. Growth and elemental composition of tomato as affected by fungicides and nitrogen sources. J. Plant Nutr. 13:1167-1177.

Stamps, R.H. and A.R. Chase. 1988. Benlate and manzate sprays do not decrease leatherleaf fern carbonassimilation, transpiration, light compensation point or vase life. Cut Foliage Grower 3(6):1-4.

Stumpff, N.J. and D.B. South. 1991. Benomyl root dips adversely affect first-year performance of stored loblolly pine seedlings. South. J. Appl. For. 15:133-137.

Tang, C.S., K. Yanagihara, and Y. Zhang. 1992. 1-Butyl isocyanate from aqueous Benlate formulations. Arch. Environ. Contam. Toxicol. 23:270 272

Tang, C.S., Y. Zhang, A.B.K. Yee, and K. Yanagihara. 1993. Effect of temperature on the evolution of $n$-butyl isocyanate from aqueous Benlate formulations. Arch. Environ. Contam. Toxicol. 25:516-519.

Thomas, T.H. 1974. Investigations into the cytokinin-like properties of benzimidazole-derived fungicides. Ann. Appl. Biol. 76:237-241.

Tripathi, R.K., K. Tandon, E. Schlösser, and W.M. Hess. 1982. Effects of fungicides on the physiology of plants. Part IV: Protection of cellular organelles of senescent wheat leaves by carbendazim. Pesticide Sci. 13:395-400

Upham,P.M. and C.J. Delp. 1973. Role of benomyl in the systemic control of fungi and mites on herbaceous plants. Phytopathology 63:814-820.

Van Assche, C. and A. Vanachter. 1970. Systemic fungicides to control fungal diseases in vegetables. Parasitica 26:117-126.

van Faassen, H.G. 1974. Effects of the fungicide benomyl on some metabolic processes, and on the numbers of bacteria and actinomycetes in the soil. Soil Biol. Biochem. 6:131-133.

Wensley, R.N. 1972. Effects of benomyl and two related systemic fungicides on growth of fusarium wilt-susceptible and resistant muskmelon. Can. J. Plant Sci. 52:775-779

Wensley, R. N. and C.M. Huang. 1970. Control of Fusarium wilt of muskmelon and other effects of benomyl soil drenches. Can. J. Microbiol. 16:615-620.

Woo, Y.M. and S.M. Wick. 1995. Effects of Benlate 50 DF on microtubules of cucumber root tip cells and on growth of cucumber seedlings. Amer. J. Bot. 82:496-503.

Wood, B., T. Gottwald, and J. Payne. 1984. Influence of single applications of fungicides on net photosynthesis of pecan. Plant Dis. 68:427428.

Yamaguchi, J. 1978. Respiration and the growth efficiency in relation to crop productivity. J. Faculty Agr., Hokkaido Univ. 59:59-129. 